\title{
Discovery of an Antibody Against SARS-CoV-2-RBD (Receptor Binding Domain)
}

\author{
Claire Lee, Seungjae Kim, Ha Ryeong Eo, Christine Yi \\ Seoul International School, Dong pangyo-ro 155, Bundang-gu, Seongnam-si, Gyeonggi-do, 13525, South Korea; \\ christine.yi22@stu.siskorea.org
}

ABSTRACT: The novel SARS-CoV-2 is the causative agent of the recent COVID-19 pandemic and has claimed more than 3 million lives worldwide. The spike protein is a viral transmembrane protein of the SARS-CoV-2 that binds to receptors on target cells, making it responsible for cell entry. The $\mathrm{S} 1$ subunit of the Spike protein contains the receptor-binding domain (RBD), which strongly binds to the angiotensin-converting enzyme 2 (ACE2) receptor of human cells. Therefore, the purpose of this study was to discover a neutralizing antibody against SARS-CoV-2-RBD that could potentially be used to develop a combined postexposure therapy for SARS-CoV-2 infection. Phage display biopanning and ELISA assays were performed to isolate single chain variable fragment $(\mathrm{scFv}$ ) antibodies binding to SARS-CoV-2-RBD from the phage display library. The ELISA assays resulted in a total of nine positive binders, and of those nine, two scFv antibodies carrying unique DNA sequences were identified. However, additional protein sequence analysis by ExPASy revealed the presence of stop codons in both antibody sequences, making the antibodies inapplicable for further therapeutic development. Taken together, the phage display biopanning strategy described here provides a promising basis for isolating a clinically applicable neutralizing antibody against SARS-CoV-2-RBD.

KEYWORDS: Biomedical and Health Science; Genetics and Molecular Biology of Disease; Phage display; SARS-CoV-2; RBD.

\section{- Introduction}

Coronaviruses $(\mathrm{CoV})$ are a large group of viruses that can cause a range of illnesses in vertebrates. ${ }^{1}$ Within the past two decades, two highly pathogenic coronaviruses with zoonotic origin - severe acute respiratory syndrome coronavirus (SARS$\mathrm{CoV}$ ) and Middle East respiratory syndrome coronavirus (MERS-CoV) - have caused large-scale outbreaks of infectious diseases. ${ }^{2}$ The novel severe acute respiratory syndrome coronavirus $^{2}$ (SARS-CoV-2), the causative agent of the recent COVID-19 pandemic, first emerged in Wuhan, China, at the end of 2019. It is a highly transmissible virus and the third most pathogenic coronavirus that causes mild to severe respiratory infections in humans. On January 30th, 2020, the World Health Organization (WHO) declared COVID-19 as the sixth public health emergency of international concern, and as of April 18th, 2021, about 130 confirmed cases and 3 million deaths have been reported worldwide.

SARS-CoV-2 is an enveloped virus with a positivesense, single-stranded RNA genome. ${ }^{3}$ SARS-CoV-2 entry into host cells is mediated by its transmembrane spike (S) glycoprotein. The $\mathrm{S}$ glycoprotein is responsible for binding to the host cell receptor and for the fusion of the viral and cellular membranes. ${ }^{4}$ The $\mathrm{S} 1$ subunit of the $\mathrm{S}$ glycoprotein contains the receptor-binding domain (RBD), which binds to the host cell receptor angiotensin-converting enzyme 2 (ACE2), initiating viral cell entry. ${ }^{5}$ Therefore, this receptor interaction site on the S1 subunit is considered the main target for therapeutic monoclonal antibodies. ${ }^{6}$

Accordingly, the main objective of this study is to discover and isolate an antibody that will bind to the receptor-binding domain (RBD) of SARS-CoV-2. Herein, the phage display technique was utilized to present the peptide sequences on the surface of bacteriophages, and the scFv antibody sequences were inserted into a vector, creating a phagemid that was placed inside the bacteriophage. An antibody that strongly binds to the receptor-binding domain of SARS-CoV-2 would function as a neutralizing antibody that prevents the infectivity of SARS-CoV-2 and potentially serve as a therapeutic agent in the development of a combined post-exposure therapy against SARS-CoV-2 infection.

\section{Methods}

Phage display technique and ELISA screening were used to isolate specific $\mathrm{scFv}$ antibodies against SARS-CoV-2-RBD. A phage display library containing bacteriophages each displaying different $\mathrm{scFv}$ antibodies was constructed prior to the experiment. The scFv library was subjected to three rounds of biopanning, and positive phage clones were identified through ELISA screening. The DNA and protein sequences of the positive $s c F v$ clones were analyzed (Figure 1).
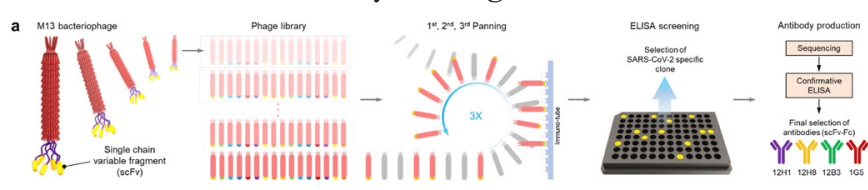

Figure 1: Description of the overall methodology. ${ }^{7}$

\section{Selection of scFv antibodies using phage display:}

scFv phage display library, Escherichia Coli TG1 strain, and M13 helper phage were obtained from YntoAb. In each round of panning, $5 \mu \mathrm{g}$ of SARS-CoV-2-RBD in $1 \mathrm{~mL}$ of sodium carbonate buffer ( $\mathrm{pH}$ 9.2) was coated on an immune tube 7 and 
incubated at $4{ }^{\circ} \mathrm{C}$ overnight. The following day, the tube was blocked with $3 \%$ skim milk (1XPBS) for 30 minutes at room temperature. Phage particles were pre-incubated with $3 \%$ skim milk for 30 minutes to remove their reactivity against skim milk proteins and were added directly to the RBD-coated immune tube. After washing five times with 1 XPBS containing detergent, bound phages were eluted with $1 \mathrm{ml} 100 \mathrm{mMTEA}$ for 8 minutes at room temperature and neutralized with 500 $\mu 11$ M Tris- $\mathrm{Cl}$ ( $\mathrm{pH} 7.4$ ). $8.5 \mathrm{ml}$ of E.coli TG1 strain was then infected with the eluted phage particles and incubated at 37 ${ }^{\circ} \mathrm{C}, 130 \mathrm{rpm}$ for 60 minutes (the TG1 strain was cultivated in an LB agar plate containing Ampicillin and Kanamycin prior to this step to check for contamination). $1 \mu \mathrm{l}$ of infected TG1 was placed in a $100 \mu \mathrm{l}$ growth medium and spread on a $90 \mathrm{~mm}$ LB agar plate containing Ampicillin, which was later used to approximate the number of infected colonies. The remaining bacterial culture was pelleted by centrifugation at $3000 \mathrm{rpm}$ for 5 minutes, spread on a $150 \mathrm{~mm} \mathrm{LB}$ agar plate containing Ampicillin, and incubated overnight at $37^{\circ} \mathrm{C} .4 \mathrm{~mL}$ of growth medium was then added to the $150 \mathrm{~mm}$ plate to scrape the bacterial colonies. After re-suspending the solution, $50 \mu \mathrm{l}$ of infected bacteria were inoculated into $20 \mathrm{~mL}$ of SB-ampicillin growth medium and placed in a shake incubator $37^{\circ} \mathrm{C}, 220$ rpm for 1.5 hours for bacterial growth. The remaining bacterial culture was kept at $-80{ }^{\circ} \mathrm{C}$ in $50 \%$ glycerol for long-term storage.

Following incubation, the phage library was rescued by infection with $1 \mathrm{ml}$ of M13 helper phage. Kanamycin (1:1000) was added directly to the TG1 strain during the rescue process and incubated overnight at $30{ }^{\circ} \mathrm{C}, 200 \mathrm{rpm}$ to increase efficiency by removing uninfected bacteria. The following day, the bacterial cells were removed from the medium by centrifugation $\left(3500 \mathrm{rpm}, 15 \mathrm{~min}, 4^{\circ} \mathrm{C}\right)$. Escaped phage particles bound to $5 \mathrm{X}$ PEG (Figure 2) were pelleted by centrifugation $(15,000$ $\mathrm{Xg}, 30 \mathrm{~min}, 4^{\circ} \mathrm{C}$ ). $550 \mu \mathrm{l}$ of $1 \mathrm{X}$ PBS (with protease inhibitor cocktail without EDTA, pH 7.4) was added to the phage particles to inhibit the breakdown of proteins. The phage particles were once again pelleted by centrifugation $(12,000 \mathrm{rpm}, 5 \mathrm{~min}$, $4{ }^{\circ} \mathrm{C}$ ) and filtered through a $0.2 \mu \mathrm{M}$ filter syringe to remove any possible bacteria debris. Succeeding rounds of panning were performed following the identical procedure but with increased washing stringency. The RBD output for the first, second, and third rounds of panning was $8 \times 105,4.4 \times 105$, and $6.26 \times 107$, respectively.

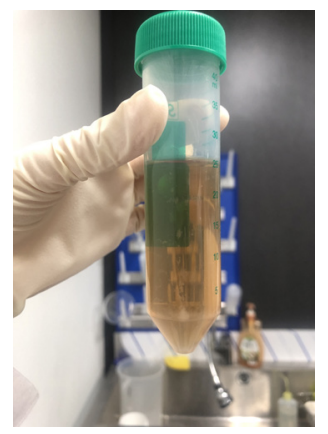

Figure 2: Escaped phage particles bound to $5 \mathrm{X}$ PEG pelleted by centrifugation.

\section{Seeding and Induction:}

After the third round of selection, individual bacterial colonies were inoculated into 96-well-plates each containing 100 $\mu 1 \mathrm{SB}$-ampicillin (Figure 3), followed by overnight incubation at $220 \mathrm{rpm}, 30{ }^{\circ} \mathrm{C} .15 \mu \mathrm{l}$ from each well was moved to a new set of 96-well-plates each containing $165 \mu \mathrm{l} \mathrm{SB}$-ampicillin and incubated at $37^{\circ} \mathrm{C}, 220 \mathrm{rpm}$ for 90 minutes. The remaining bacteria in the original well-plate was stored at $-80^{\circ} \mathrm{C}$ with $40 \mu \mathrm{l}$ of $50 \%$ glycerol to prevent rapid re-crystallization. $20 \mu \mathrm{l}$ IPTG was added to the incubated 96-well-plates to inactivate the repressor for continuous transcription and incubated overnight at $30^{\circ} \mathrm{C}, 200 \mathrm{rpm}$.

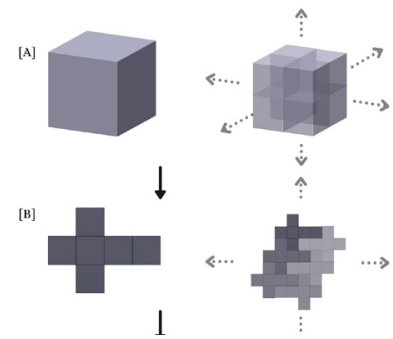

Figure 3: Individual bacterial colonies incubated with SB-ampicillin.

\section{Periplasmic Sup Preparation:}

The incubated bacterial culture induced with IPTG was centrifuged at 3,000 rpm for 10 minutes at $4{ }^{\circ} \mathrm{C} .80 \mu \mathrm{l}$ of $1 \mathrm{X}$ TES buffer was added and vortexed, followed by incubation on ice for 30 minutes. Then, $120 \mu \mathrm{l}$ of $0.2 \mathrm{X}$ TES buffer was added and vortexed, followed by incubation on ice for 30 minutes. Centrifugation was carried out at 3,000 rpm for 10 minutes at $4{ }^{\circ} \mathrm{C}$, and the supernatant (periplasmic sup) containing soluble scFvs was taken directly for ELISA screening.

\section{Periplasmic Sup Preparation:}

The incubated bacterial culture induced with IPTG was centrifuged at $3,000 \mathrm{rpm}$ for 10 minutes at $4{ }^{\circ} \mathrm{C} .80 \mu \mathrm{l}$ of $1 \mathrm{X}$ TES buffer was adde

\section{Enzyme-linked Immunosorbent Assay (ELISA):}

$5 \mu \mathrm{g}$ of SARS-CoV-2-RBD was coated on a 96-well ELISA plate following the same immobilization method described above. The RBD-coated wells were each blocked with $150 \mu 13 \%$ skim milk (1X PBS) for 30 minutes at room temperature. Additionally, a negative control was prepared by coating the $3 \%$ skim milk on a separate empty ELISA plate. $50 \mu \mathrm{l}$ of periplasmic sup was added to each of the wells in both the RBD-coated plate and the negative control. The plates were left at room temperature for 30 minutes. The plates were washed 3 times with $150 \mu$ l of 1 X PBS detergent to remove any unbound or nonspecific binding proteins. 50 $\mu \mathrm{l}$ of secondary antibody (anti-HA peroxidase) ${ }^{8}$ suspended in 3\% skim milk was added to the wells and incubated for 30 minutes. The addition of the secondary antibody to the primary antibody produces a fluorescent signal due to the reaction between the HA Tag and the Anti-HA peroxidase. ${ }^{9}$ After washing 3 times with $150 \mu$ of $1 \mathrm{X}$ PBS detergent, 50 $\mu \mathrm{l}$ of TMB substrate was added to each of the wells and left at room temperature for 5 minutes. The substrate reaction was stopped with $50 \mu$ lof sulfuric acid (Figure 4). The optical density (OD) values were measured at $450 \mathrm{~nm}$ using the ELISA 
reader (Table 1, Table 2). The positive clones were identified with OD450nm values above 1.0. Overall, the ELISA assays resulted in 9 positive binders.

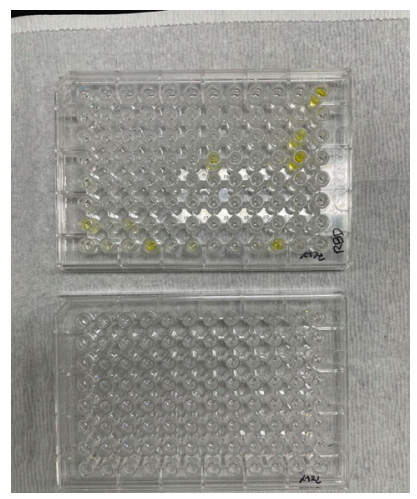

Figure 4: 96-well-plates after the addition of $\mathrm{H}_{2} \mathrm{SO}_{4}$.

Table 1: RBD ELISA results (using ELISA reader from BIOTECH).

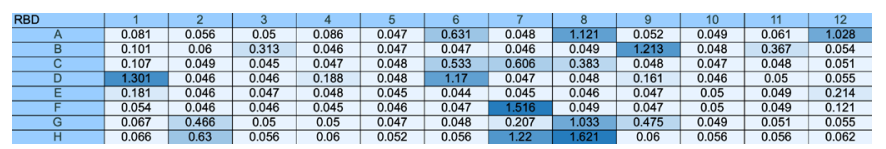

Table 2: 3\% skim milk ELISA results (negative control).

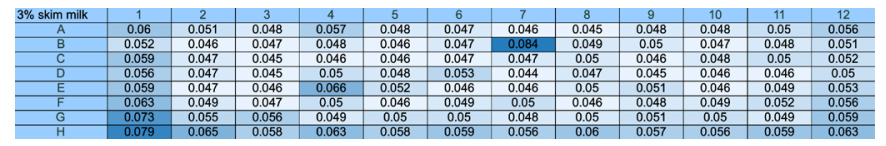

OD450nm values above 1.0 were identified as positive. The negative control did not yield any positive binders, verifying that the antibodies with $\mathrm{OD}_{450 \mathrm{~nm}}>1.0$ in Table 1 bind specifically to RBD. A total of 9 samples were carried on to the sequencing stage.

\section{Seeding:}

The 96 -well stock stored at $-80{ }^{\circ} \mathrm{C}$ was allowed to thaw at room temperature. $5 \mu \mathrm{l}$ of each of the 9 positive binders were taken from the 96-well stock and mixed with $2 \mathrm{ml}$ of SB-ampicillin in $15 \mathrm{ml}$ tubes, followed by incubation overnight at 37 ${ }^{\circ} \mathrm{C}, 200 \mathrm{rpm}$.

\section{DNA Minipreparation:}

$1.4 \mathrm{ml}$ from each bacterial culture was moved to $1.5 \mathrm{ml}$ tubes. The bacterial cells were pelleted by centrifugation at $12,000 \mathrm{rpm}$ for 5 minutes at $4{ }^{\circ} \mathrm{C} .250 \mu \mathrm{l}$ of $\mathrm{P} 1$ buffer containing EDTA was added to destabilize the cell walls. $250 \mu 1$ of P2 buffer containing $\mathrm{NaOH}$ was added for alkaline lysis, which disrupts the hydrogen bonding between the DNA bases and causes both bacterial and phage DNA to denature. $350 \mu$ of P3 buffer containing acetic acid was added for neutralization, allowing the DNA to precipitate. Centrifugation was carried out at $12,000 \mathrm{rpm}$ for 10 minutes at $4{ }^{\circ} \mathrm{C}$ to separate the phage DNA from the bacterial DNA. The supernatant containing the phage DNA was filtered through a miniprep tube column (provided by YntoAb) and centrifuged at 12,000 rpm for 60 seconds at $4{ }^{\circ} \mathrm{C}$. The filtrate was thrown away, and $500 \mu \mathrm{l}$ of ethanol-based EW buffer was added to the tube column, followed by centrifugation. The same procedure was repeated with $700 \mu$ of ethanol-based PW buffer. After replacing the tube with a new one, $50 \mu \mathrm{l}$ of DW was added directly to the column and centrifuged at $12,000 \mathrm{rpm}$ for 60 seconds at $4{ }^{\circ} \mathrm{C}$.
The filtrate containing the phage DNA was quantified using TAKE3 (Table 3) and sent for sequencing.

Table 3: DNA quantification results (using TAKE 3 equipment from BIOTECH). *Concentration ( $\mathrm{ng} / \mu \mathrm{L})$ based on Beer-Lambert's law, concentration $=$ absorbance $\mathrm{x}$ constant $(50 \mathrm{ug} / \mathrm{ml}$ for DNA) $\mathrm{x}$ dilution factor

\begin{tabular}{|l|l|l|l|l|}
\hline Sample ID & Absorbance_260 & Absorbance_280 & $\begin{array}{l}\text { O.D. Ratio } \\
(260 / 280)\end{array}$ & $\begin{array}{l}\text { DNA } \\
\text { Concentration } \\
(\mathrm{ng} / \mu \mathrm{L})^{*}\end{array}$ \\
\hline A8 & 0.089 & 0.046 & 1.951 & 88.919 \\
\hline A12 & 0.044 & 0.021 & 2.148 & 44.15 \\
\hline B9 & 0.056 & 0.027 & 2.06 & 55.963 \\
\hline D1 & 0.178 & 0.095 & 1.872 & 178.043 \\
\hline D6 & 0.269 & 0.145 & 1.864 & 269.384 \\
\hline F7 & 0.2 & 0.107 & 1.863 & 200.132 \\
\hline G8 & 0.025 & 0.014 & 1.805 & 24.788 \\
\hline H7 & 0.485 & 0.263 & 1.842 & 484.598 \\
\hline H8 & 0.317 & 0.168 & 1.893 & 317.233 \\
\hline
\end{tabular}

Using the quantification results, DNA purity and DNA concentration were measured. DNA is quantified at $260 \mathrm{~nm}$, and proteins are quantified at $280 \mathrm{~nm} .{ }^{10}$ DNA to protein (260/280) ratios greater than 1.6 1.8 were considered high DNA purity. ${ }^{10}$

\section{- Results and Discussion \\ Results:}

The 9 positive binders identified by the ELISA assays were carried on to the sequencing stage. DNA from individual phage clones was isolated to obtain specific nucleotide sequences, represented by four-color chromatograms. Of the 9 positive binders, only 2 of the scFv antibodies displayed regular, evenly spaced peaks (Figure 5, Figure 6).

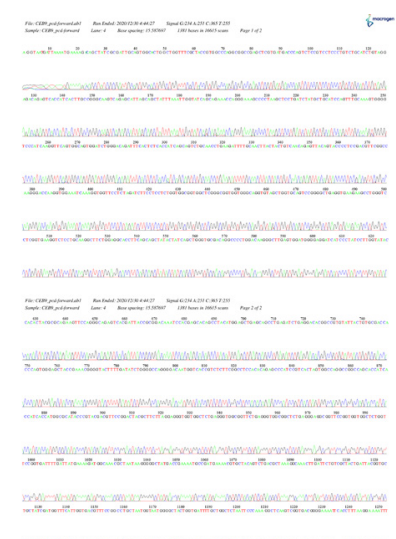

Figure 5: B9 sequencing results.

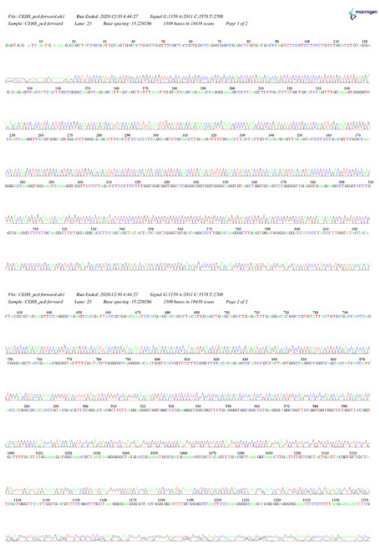

Figure 6: $\mathrm{H} 8$ sequencing results. 
Antibodies with irregular peaks were omitted at this stage. Antibodies with regular peaks as shown in Figure 5 and Figure 6 were further processed. ExPASy, an online translational tool, was used to deduce the protein sequences as shown in Figure 7 and Figure 8.

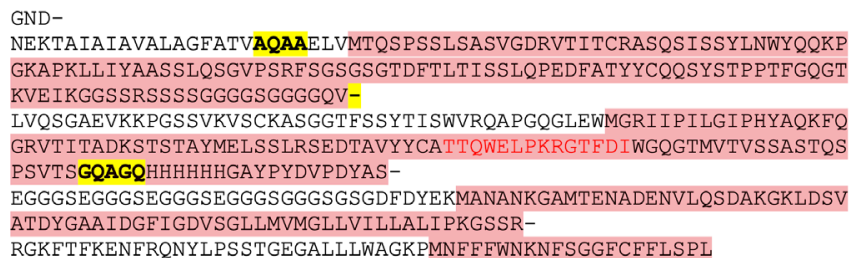

RGKFTFKENFRQNYLPSSTGEGALLLWAGKPMNFFFWNKNFSGGFCFFLSPL

Figure 7: $\mathrm{B} 9$ protein sequence.

VDQ-

KTAIAIAVALAGFATVAQAAELVMTQSPSSLSASVGDRVTITCRASQS ISSYLNWYQQKPGK APKLLIYAASSLQSGVPSRF SGSGSGTDFTLTISSLQPEDFATYYCQQSYSTPPTFGQGTKV EIKGGSSRSSSSGGGGSGGGGQV-

LVOSGAEVKKPGSSVKVSCKASGGTFSSYTISWVROAPGOGLEWMGRI IPILGIPHYAOKFO GRVTITADKSTSTAYMELSSLRSEDTAVYYCATTQWELPKRGTFDIWGQGTMVTVSSASTQS PSVTSGQAGQHHHHHHGAYPYDVPDYAS-EGGGSEGWRF-GWRL-GRRFRWWLWFR-F-LKDGKR--GGYDRKCR-KRATV-R-RQT-FCRY-LRCCYRWVHW-RFRPC-

GEGATGGFCGAQF PKGQVGEGEIPL-

EKIRPNYFLPTPVEGGPLFLGGEKKKFFLLGKKKI PGAWFFF I PPF IFFFLTPEKGGHFLPP PGGGRGGVILFFFFFPFTPHPSL-GSK

Figure 8: $\mathrm{H} 8$ protein sequence.

AQAA and GQAGQ mark restriction enzyme sites. ${ }^{11}$ The his6-tag, linker, and HA-tag were all successfully translated in both Figure 7 and Figure 8. However, the stop codons (represented by a dash) between the restriction enzyme sites make both sequences inapplicable for mammalian cells. ${ }^{12}$ Bacteria TG1 can convert stop codons so that the gene can be expressed, which suggests why positive ELISA results were yielded in experimental conditions. However, mammalian cells cannot translate stop codons and therefore this sequence is not applicable to mammalian cells. ${ }^{11}$ To summarize, sequences containing stop codons between restriction enzyme markings do not code for a viable antibody against RBD. ${ }^{11}$ In other words, sequences that do not contain stop codons between restriction enzyme markings must be discovered in order for them to be applicable to mammalian cells.

\section{Discussion:}

Two RBD-specific scFv antibodies carrying unique sequences were isolated from the phage display library. Positive ELISA results confirm that both antibodies bind specifically to SARS-CoV-2-RBD and not to 3\% skim milk. However, additional protein sequence analysis by ExPASy revealed the presence of stop codons in both antibody sequences. Thus, despite their specificity to the RBD, both $s c F v$ antibodies are inapplicable for further therapeutic development or diagnostic tests against SARS-CoV-2. Nevertheless, the results of this study highlight the possibility of isolating clinically applicable neutralizing antibodies specific to SARS-CoV-2RBD by phage display biopanning. These antibodies would be considered promising candidates for the development of a post-exposure therapy against COVID-19 infection.

As a modification, following the same procedure but with a different phage display library or with additional panning can help isolate RBD-specific scFv antibodies with intact protein sequences. Increasing the number of washing or increasing the washing stringency can also increase the selectivity and hence exclude weakly binding antibodies. Further investigation can involve a slight modification in methodology such as substituting the immune tube coating stage with immobilized proteins on beads.

\section{- Conclusion}

In this study, we sought to discover an antibody against SARS-CoV-2-RBD. From our scFv library, no viable antibodies were found. While 2 RBD-specific antibodies carrying unique sequences were isolated and characterized, the presence of stop codons in their protein sequences make them inapplicable to mammalian cells. Further attempts to isolate an $\mathrm{scFv}$ antibody that is ultimately applicable to mammalian cells will be made using a different phage display library.

\section{Acknowledgements}

We thank YntoAb for providing us with an equipped laboratory.

\section{References}

1. Hu, B., Guo, H., Zhou, P. et al. Characteristics of SARS-CoV-2 and COVID-19. Nat Rev Microbiol 19,141-154 (2021). https:// doi.org/10.1038/s41579-020-00459-7

2. Andersen, K.G., Rambaut, A., Lipkin, W.I. et al. The proximal origin of SARS-CoV-2. Nat Med 26, 450-452 (2020). https://doi. org/10.1038/s41591-020-0820-9

3. SARS. https://www.cdc.gov/sars/index.html (accessed Feb 17, 2021).

4. Schoeman, D., Fielding, B.C. Coronavirus envelope protein: current knowledge. Virol J 16, 69 (2019). https://doi.org/10.1186/s12985019-1182-0

5. Machhi, J., Herskovitz, J., Senan, A.M. et al. The Natural History, Pathobiology, and Clinical Manifestations of SARS-CoV-2 Infections.J Neuroimmune Pharmacol 15, 359-386 (2020). https://doi.org/10.1007/s11481-020-09944-5

6. Kruse RL. Therapeutic strategies in an outbreak scenario to treat the novel coronavirus originating in Wuhan, China [version 2; peer review: 2 approved]. F1000Research 2020, 9:72 (https://doi. org/10.12688/f1000research.22211.2)

7. Kim, H.-Y.; Lee, J.-H.; Kim, M. J.; Park, S. C.; Choi, M.; Lee, W.; Ku, K. B.; Kim, B. T.; Park, E. C.; Kim, H. G.; Kim, S. I. Development of a SARS-CoV-2-Specific Biosensor for Antigen Detection Using $\mathrm{ScF}_{\mathrm{v}}-\mathrm{Fc}$ Fusion Proteins. Biosensors and Bioelectronics 2021.

8. Clark, M. F.; Lister, R. M.; Bar-Joseph, M. ELISA Techniques. Methods in Enzymology 2004, 742-766. https://doi. org/10.1016/0076-6879(86)18114-6

9. Lin A.V. (2015) Indirect ELISA. In: Hnasko R. (eds) ELISA. Methods in Molecular Biology, vol 1318. Humana Press, New York, NY. https://doi.org/10.1007/978-1-4939-2742-5_

10.Haque, K.A., Pfeiffer, R.M., Beerman, M.B. et al. Performance of high-throughput DNA quantification methods. BMC Biotechnol 3, 20 (2003). https://doi.org/10.1186/1472-6750-3-20

11.Gasteiger, Elisabeth \& Gattiker, Alexandre \& Hoogland, Christine \& Ivanyi, Ivan \& Appel, Ron \& Bairoch, Amos. (2003). ExPASy: The proteomics server for in-depth protein knowledge and analysis. Nucleic acids research. 31. 3784-8. 10.1093/nar/ gkg563.

12.DNA Miniprep protocol handbook, 2020.

\section{Authors}

Claire Lee is currently a senior at Chadwick International, an international school located in Incheon, South Korea. As her interests lie in biological sciences, her choices for majors 
are biology and/or pre-dentistry.

Seungjae Kim is a current junior that attends Chadwick International School. He is interested in neuroscience and molecular biology. He has received awards in International Genetically Engineered Machine (IGEM) 2019 and Korean Science and Engineering Fair (2020). He is also a participant of Genius Olympiad 2021.

Haryeong Eo is currently a sophomore attending Shanghai American School Puxi. It was her pleasure to participate in this amazing research for the first time and serve as a team member. She hopes this experience will help set the groundwork for studying biomedical engineering.

Christine Yi is a junior at Seoul International School in South Korea. She is heavily interested in neuroscience, medicine, and molecular biology, and has partaken in various research projects. As an aspiring pre-med student, she spends her time volunteering in nursing homes and professional laboratories. 